\title{
Accounting for Carbon Stocks in Soils and Measuring GHGs Emission Fluxes from Soils: Do We Have the Necessary Standards?
}

\begin{abstract}
Antonio Bispo ${ }^{1 *}$, Lizzi Andersen ${ }^{2}$, Denis A. Angers ${ }^{3}$, Martial Bernoux ${ }^{4}$, Michel Brossard ${ }^{5}$, Lauric Cécillon ${ }^{6}$, Rob N. J. Comans ${ }^{7}$, Joop Harmsen ${ }^{8}$, Knut Jonassen ${ }^{9}$, Frank Lamé ${ }^{10}$, Caroline Lhuillery ${ }^{11}$, Stanislav Maly ${ }^{12}$, Edith Martin ${ }^{1}$, Angus E. Mcelnea ${ }^{13}$, Hiro Sakai ${ }^{14}$, Yoichi Watabe ${ }^{15}$ and Thomas K. Eglin ${ }^{1}$

1 Direction Productions et Energies Durables, French Environment and Energy Management Agency (ADEME), Angers, France, ${ }^{2}$ COWI A/S, Kongens Lyngby, Denmark, ${ }^{3}$ Agriculture and Agri-Food Canada, Québec, QC, Canada, ${ }^{4}$ Eco\&Sols, IRD, Montpellier, France, ${ }^{5}$ Eco\&Sols, IRD, Cayenne, France, ${ }^{6}$ Université Grenoble Alpes, IRSTEA, St-Martin-d'Hères, France, ${ }^{7}$ Department of Soil Quality, Wageningen University, Wageningen, Netherlands, ${ }^{8}$ Department Sustainable Soil Management, Wageningen Environmental Research (Alterra), Wageningen, Netherlands, ${ }^{9}$ Standards Norway, Lysaker, Norway,

${ }^{10}$ Department of Soil and Groundwater Systems, Deltares, Utrecht, Netherlands, ${ }^{11}$ AFNOR Normalisation, Industry and Environment, La Plaine Saint-Denis, France, ${ }^{12}$ Central Institute for Supervising and Testing in Agriculture, Brno, Czechia, ${ }^{13}$ Department of Science, Information Technology and Innovation, Queensland Government, Brisbane, QLD, Australia, ${ }^{14}$ Railway Technical Research Institute, Japan Railways, Tokyo, Japan, ${ }^{15}$ Soil Mechanics Laboratory, School of Engineering, Hokkaido University, Hokkaido, Japan
\end{abstract}

Consejo Superior de Investigaciones Científicas (CSIC), Spain

Reviewed by:

Daniel P. Rasse,

Norwegian Institute for Bioeconomy

Research (NIBIO), Norway

Tim J. Clough,

Lincoln University, New Zealand

*Correspondence: Antonio Bispo antonio.bispo@ademe.fr

Specialty section: This article was submitted to Soil Processes

a section of the journal

Frontiers in Environmental Science

Received: 09 February 2017 Accepted: 15 June 2017

Published: 12 July 2017

Citation:

Bispo A, Andersen L, Angers DA, Bernoux M, Brossard M, Cécillon L,

Comans RNJ, Harmsen J,

Jonassen K, Lamé F, Lhuillery C,

Maly S, Martin E, Mcelnea AE,

Sakai $H$, Watabe $Y$ and Eglin TK (2017) Accounting for Carbon Stocks

in Soils and Measuring GHGs

Emission Fluxes from Soils: Do We Have the Necessary Standards?

Front. Environ. Sci. 5:41.

doi: 10.3389/fenvs.2017.00041
Soil is a key compartment for climate regulation as a source of greenhouse gases (GHGs) emissions and as a sink of carbon. Thus, soil carbon sequestration strategies should be considered alongside reduction strategies for other greenhouse gas emissions. Taking this into account, several international and European policies on climate change are now acknowledging the importance of soils, which means that proper, comparable and reliable information is needed to report on carbon stocks and GHGs emissions from soil. It also implies a need for consensus on the adoption and verification of mitigation options that soil can provide. Where consensus is a key aspect, formal standards and guidelines come into play. This paper describes the existing ISO soil quality standards that can be used in this context, and calls for new ones to be developed through (international) collaboration. Available standards cover the relevant basic soil parameters including carbon and nitrogen content but do not yet consider the dynamics of those elements. Such methods have to be developed together with guidelines consistent with the scale to be investigated and the specific use of the collected data. We argue that this standardization strategy will improve the reliability of the reporting procedures and results of the different climate models that rely on soil quality data.

Keywords: soil, carbon sequestration, methane, nitrous oxide, standards

\section{INTRODUCTION}

Soil is involved in the biogeochemical cycles of carbon (C) and nitrogen (N), and thus is a key compartment for climate regulation either by emitting greenhouse gases (GHGs) or by sequestering $\mathrm{C}$ (Figure 1). Soil stores vast amounts of C: the first meters of mineral soils contain between 1,500 and 2,400 Pg of organic C (Jobbàgy and Jackson, 2000; Ciais et al., 2013; Stockmann et al., 2013 


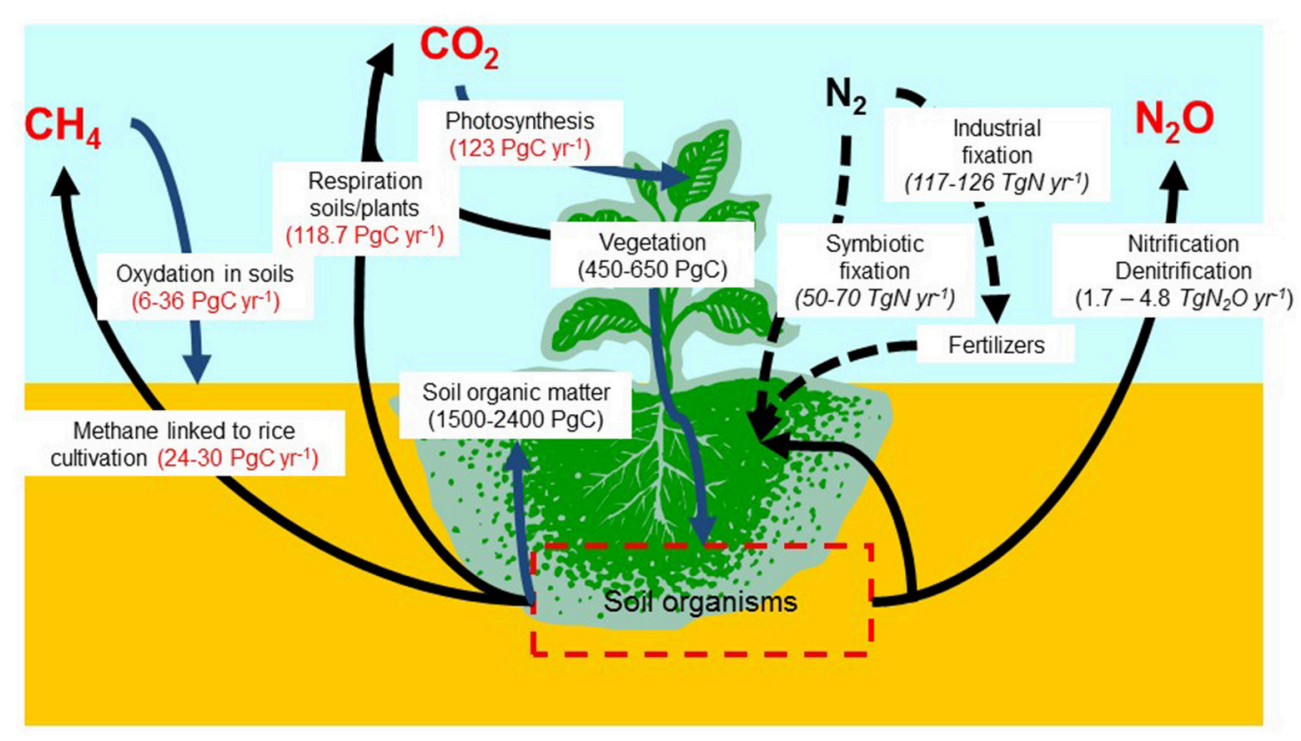

FIGURE 1 | Soil and GHGs fluxes (adapted from Ciais et al., 2013).

This is about three to four times the amount of $\mathrm{C}$ in vegetation (450-650 PgC) and twice to three times the amount in the atmosphere $(\sim 829 \mathrm{GtC})$. Moreover, peat soils and permafrost account for more than $1,500 \mathrm{Pg}$ of $\mathrm{C}$. Concerning emissions, $\mathrm{CO}_{2}$ is released from soils due to biological decay of plant litter and soil organic matter (Janzen, 2004; Smith, 2004). Together with the respiration of vegetation it represents a flux of 118.7 $\mathrm{PgC}$ a year, which is less than the photosynthesis flux (123 $\left.\mathrm{PgC} \mathrm{yr}^{-1}\right)$ actually turning land into a sink. Methane $\left(\mathrm{CH}_{4}\right)$ is produced when organic materials decompose in oxygen-depleted conditions, such as in rice paddies or under flooded conditions (Mosier et al, 1998). Rice cultivation is responsible for 24-30 Pg $\mathrm{C}$ a year that is nearly half of the emissions originating from livestock. Nitrous oxide $\left(\mathrm{N}_{2} \mathrm{O}\right)$ is part of the global $\mathrm{N}$ cycle and is linked with other forms of $\mathrm{N}$ (e.g., organic, ammonia, nitrate). In soil, $\mathrm{N}_{2} \mathrm{O}$ is generated by the microbial transformation of organic and mineral $\mathrm{N}$, and is often enhanced under wet conditions (Smith and Conen, 2004; Oenema et al., 2005). Emissions from soil, linked to cultivation are estimated between 1.7 and $4.8 \mathrm{Tg}$ $\mathrm{N}_{2} \mathrm{O}$ a year and are the main anthropic source.

Soil organic carbon (SOC) is the balance between plant inputs and biologically mediated losses. The amount of SOC is large compared to anthropogenic $\mathrm{CO}_{2}$ fluxes to the atmosphere (Figure 1), that small changes in the SOC pool could have a major impact on the concentration of $\mathrm{CO}_{2}$ in the atmosphere (Cox et al., 2000; Crowther et al., 2016). This can be seen as a threat, but also as an opportunity for possible mitigation measures. In order to be able to quantify these stocks and fluxes reliable methods are needed. Even though several models have been developed to estimate and forecast the fluxes of GHGs (e.g., Parton et al., 1994; Del Grosso et al., 2008), we still need well-defined long term field measurements to evaluate and validate their predictions. To enable this on a global scale, it is necessary to use methods that give comparable results. Standardization is a proven approach to accomplish such requirements, not only by describing complete methods, but also by developing guidelines for the use of methods that are still under development. In this paper, we evaluate the availability of required standards for quantitative assessment of the role of soil in the fluxes of GHGs and soil C stocks.

Both GHGs fluxes and C stocks in soil are complex to measure, variable, and heterogeneous as they are governed by climate (e.g., temperature, moisture regimes, $\mathrm{N}$ deposits), soil characteristics (e.g., $\mathrm{pH}$, clay content, cation exchange capacity), and for managed soils by the agricultural or forestry practices (e.g., crop and wood residues management, soil tillage, soil amendments and fertilizers, irrigation). These factors generally interact and their effects on SOC stocks and GHGs emissions are still poorly quantified (Eglin et al., 2010; Fujisaki et al., 2015). Moreover, $\mathrm{C}$ and $\mathrm{N}$ cycles are closely connected as for example organic matter decay may produce $\mathrm{CO}_{2}$ but also $\mathrm{N}_{2} \mathrm{O}$ through heterotrophic nitrification and/or denitrification (Zhang et al., 2015).

Several international and European policies are now acknowledging the importance of soils, which means that proper, comparable and reliable information is needed to report on $\mathrm{C}$ stocks and GHGs emissions from soil. It also implies a need for consensus on the adoption and verification of mitigation options that soil can provide. Therefore, the need for standards is becoming urgent to ensure comparable estimations of either C stocks or GHGs emissions. Paustian et al. (2016) together with The Global Soil Partnership in its pillar 5 (Montanarella and Vargas, 2012) call for harmonization of protocols, methods, measurements, and indicators for soil management to facilitate comparability and exchange of data. This paper reviews existing ISO standards and identifies the need for new ones to support 
climate policy requirements regarding soil processes that control C storage and GHGs emissions.

\section{POLICY NEEDS}

Policy frameworks concerning soil C and GHGs emissions have recently evolved at both the European and global level. The main driver for this is the United Nations Framework Convention on Climate Change. Within this convention, emissions of $\mathrm{N}_{2} \mathrm{O}$ and $\mathrm{CH}_{4}$ from managed soils (i.e., particularly agricultural soils) are taken into account whereas in most countries the emissions of $\mathrm{CO}_{2}$ are counted only if land use changes occur (e.g., deforestation and conversion of grasslands to croplands result in a loss of SOC). Since the COP 17 in Durban in 2011, a more holistic approach asks also for considering soil management (not only land use changes) when accounting for $\mathrm{CO}_{2}$ fluxes (UNFCCC, 2011; EU, 2013). As an example, EU asks for "new accounting rules applicable on a mandatory basis to the activities of afforestation, reforestation, deforestation, and forest management, as well as to the activities of grazing land management and cropland management, subject to specific provisions with a view to improving Member States' reporting and accounting systems during the first accounting period. This Decision should also provide for accounting rules applicable on a voluntary basis to revegetation and wetland drainage and rewetting activities." Such changes will require the development of monitoring, reporting and verification (also called MRV) systems as also stressed by the recent agreement on climate change signed in Paris (UNFCCC, 2016a). The aim is to be able to assess and monitor the impact of mitigation measures and to document this information in a transparent way so that it can be examined for accuracy. This is even more important if mitigation options based on soil management are promoted and included into financial mechanisms where a payment will be made for reducing emissions or increasing $\mathrm{C}$ stocks in soils (Thamo and Pannell, 2015). As an example, the 4\%o Initiative (4pmille.org; Lal, 2016), launched by France during COP 21, aims to demonstrate that agriculture, and agricultural soils in particular, can play a crucial role where food security and climate change are concerned. This initiative invites all partners to declare or to implement practical programmes for $\mathrm{C}$ sequestration in soil and the types of farming methods used to promote it (e.g., agroecology, agroforestry, conservation agriculture, landscape management).

Such initiatives not only underline that soil $\mathrm{C}$ is a controlling parameter in climate change, but also underline the crucial role of soil organic matter in maintaining soil fertility (Lal et al., 2007) and supporting life in soils (i.e., soil biodiversity). SOC is, therefore, also directly linked to the convention on biodiversity (UNCBD), on desertification (UNCCD) and on food security (FAO Global Soil Partnership; Montanarella, 2015; Figure 2). Sequestration of $C$ in soils can be considered as a "winwin" strategy since it can reduce vulnerability to erosion and improve soil biodiversity and fertility (UNCCD, 2015; UNFCCC, 2016b). Organic matter being such a key constituent, any strategy aimed at maintaining and increasing its content in soils will contribute to climate mitigation but also prevent or combat soil and land degradation (Sustainable Development Goals n ${ }^{\circ} 15$, https://sustainabledevelopment.un.org/sdgs; Montanarella and Alva, 2015).

To estimate GHGs emission and soil C stock changes, the Intergovernmental Panel on Climate Change (IPCC) developed a series of mathematical equations that relate data on land use and management activities to emission/storage factors to estimate fluxes from these activities (see IPCC, 2003, 2006). The methodology is based on a tiered approach depending on the scale and the quality of the data available. Briefly, tier 1 corresponds to very large-scale approaches, with average emission factors for large eco-regions of the world (e.g., boreal, temperate, and tropical). Tier 2 is similar conceptually but uses specific data linked to either a state, region, landscape, or even project. It requires more accurate emission factors usually obtained by intensive field measurements at the required scale (note that those factors need to be peer reviewed before acceptance). Tier 3 is a much more detailed approach, usually including biophysical modeling and requiring data on land use and management.

Tiers 1 and 2 calculations are based on multiplying emission factors for a given gas and source category (e.g., $\mathrm{N}_{2} \mathrm{O}$ for agricultural soils) by the information on the emission source (e.g., the area, the amount of mineral fertilizers). Several calculators have been developed for such purpose but more precise information is needed to guarantee an accurate accounting of GHGs emissions or SOC stocks (Colomb et al., 2013; Milne et al., 2013). This could be done by modeling (Tier 3) but such an approach is currently only available for a small number of emission sources (e.g., $\mathrm{N}_{2} \mathrm{O}$ soil emissions from nitrification or denitrification, see Le Gall et al., 2015) and limited to either a specific region or country (in most cases temperate regions) or a specific agricultural productions (e.g., flooded and irrigated rice). The calibration step of models with long-term datasets is a critical point (Stockmann et al., 2013), and generally such models cannot be used worldwide, for all crops, forests, and management options.

Up to now several countries have proposed Tier 2 methods based on direct measurements of soil C stocks (see for example the French and UK inventories that use $\mathrm{C}$ data from their national soil monitoring networks-Citepa, 2014; Webb et al., 2014) and $\mathrm{N}_{2} \mathrm{O}$ emissions [e.g., Canada (Rochette et al., 2008), New Zealand (Clough et al., 2007), Netherlands (Kuikman et al., 2006)]. Few Tier 3 approaches have been developed for accounting $\mathrm{C}$ stock changes in forest soils: Finland and Norway inventories use the Yasso model (Tuomi et al., 2011) and Canadian inventory uses the CBM-CFS3 model (Kurz et al., 2009). Considering emissions from agricultural soils the Danish inventory uses the C-Tool model (Taghizadeh-Toosi et al., 2014), the national GHGs Canadian inventory (Environment Canada, 2015) uses the CENTURY model (Parton et al., 1994) and $\mathrm{N}_{2} \mathrm{O}$ emissions are estimated in the US inventory with the Daycent model (Del Grosso et al., 2008).

Recently several initiatives around the world have attempted to quantify at national or at global scale the potential of soils to mitigate climate change. Chenu et al. (2014) estimated for France 


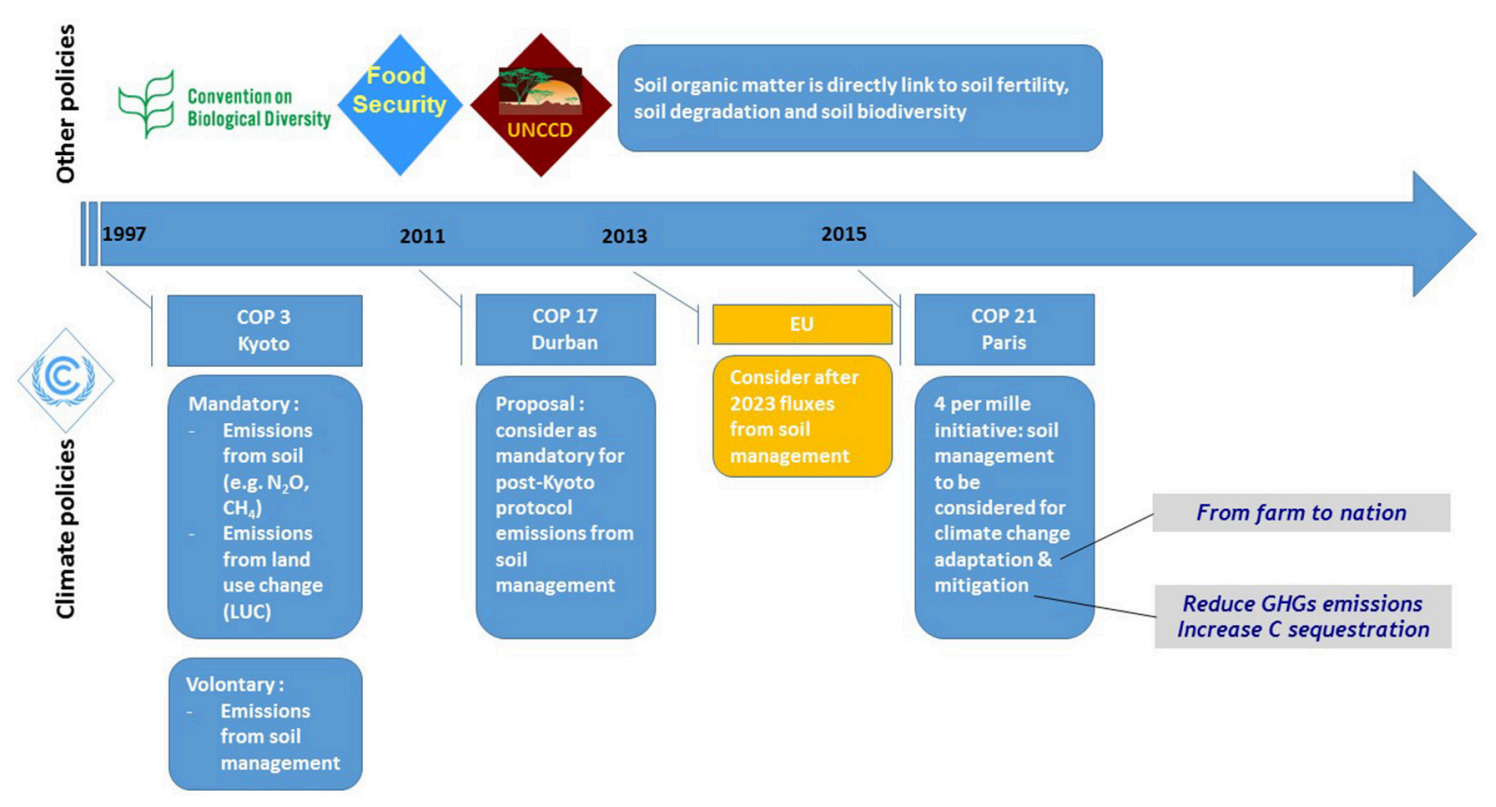

FIGURE 2 | Soil and policies: major dates.

that around 1 million tons of $\mathrm{C}$ could be sequestered annually by changing soil management (e.g., development of direct seeding). Schulte et al. (2016) proposed a framework for climate smart land management in Ireland where they combine and map soil and land information including the current soil C stocks, the potential additional SOC storage and the sensitivity of soils to emit $\mathrm{CO}_{2}$. McNally et al. (2017) estimated the $\mathrm{C}$ sequestration potential of soils from permanent pasture and continuous cropping in New Zealand using the concept of saturation deficit as previously used by Angers et al. (2011). At the global scale, Paustian et al. (2016) summarized soil management practices and estimated a potential of mitigation of around $8 \mathrm{Pg}\left(\mathrm{Co}_{2} \mathrm{eq}\right)$ a year. Minasny et al. (2017) surveyed the soil $\mathrm{C}$ stock estimates and sequestration potentials from 20 regions in the world showing that $\mathrm{C}$ sequestration in soils can contribute to mitigating climate change over the next ten to twenty years. All those approaches were based on data gathered over time and obtained with different methods for sampling and analysis. This makes results difficult to compare across the different countries or regions.

Variation of $\mathrm{C}$ stocks may also be of importance when evaluating the environmental benefits of policies like the production of bioenergy (Bispo et al., 2014). National policies on bioenergy resulted in an higher demand for agricultural feedstock (e.g., maize for bioethanol or palm oil for biodiesel) increasing the agricultural prices leading farmers in turn to increase their output, either by intensifying (i.e., applying more fertilizers) or by converting non-agricultural land (e.g., grassland or forest). The resulting land use changes (LUC) caused the release of the $\mathrm{C}$ stored in soils and in the above-ground biomass into the atmosphere (Harris et al., 2015). For the last 10 years, the total net GHGs effect of biofuels (i.e., including LUC emissions) is still debated in the scientific (Fargione et al., 2008;
Searchinger et al., 2008; Plevin et al., 2010; Zilberman, 2017) and policy arenas (European Commission, 2012, 2015). It is, therefore, crucial when performing environmental assessments to improve the quality and quantity of our information on soils (particularly SOC) not only for the assessment of sustainable energy scenarios but also for many other societal choices. The way we eat, live, and produce will modify either the use of land (e.g., meat consumption, spreading of urban areas) and the yield (e.g., development of organic agriculture) having in turn consequences for soil $\mathrm{C}$ stocks locally or elsewhere in the world (e.g., deforestation). Generic ISO documents to quantify GHGs emissions and removals for projects and organizations (ISO 14064-1, 2006; ISO 14064-2, 2006; ISO 14064-3, 2006; ISO/TR 14069, 2013) and C footprint for products (CFP) (ISO/TS 14067, 2013) exist already. Such standards facilitate a stronger focus on climate change mitigation from a business point of view. The main idea is that consumers and purchasers should have an opportunity to use $\mathrm{C}$ footprint of products as a selection criteria when purchasing goods or services. For most types of business or production processes, adequate and reliable databases, containing aggregated data based on a sufficient number of measurements, exists. For processes where soil is involved, this is not the case. Reliable and adequate, aggregated data are missing for GHGs emissions and soil C stock changes resulting from land cover and land use change as well as from processes involving change of physical, chemical and biological status when soil is utilized over time in production or other business processes.

Both climate change policies and markets call for widely accepted reliable accounting and reporting of $\mathrm{C}$ stock and stock changes and GHGs emissions. Protocols, methods, and models developed by scientists for investigating and deciphering 
processes in soils need to be translated into practical and transparent procedures. International standardization is a way to achieve such objective, as the aim is to share knowledge and reach agreement on a document (e.g., standard, guideline, technical report) that can be used worldwide. Having an international common way to measure and report is crucial to verify and control emissions and stock changes linked to variations in land use or management, and to take appropriate decisions (Figure 3).

\section{EXISTING STANDARDS}

ISO TC 190 has developed from the 1980's more than 100 standards dealing with soil description and soil analysis. Until the 1990's most of the standards were dedicated to the characterization of soil quality regarding fertility in relation to food production. Subsequently, the main emphasis shifted to the analysis of soil contaminants (e.g., trace elements, organic molecules) and the respective impact on soil living organisms (e.g., bacteria, soil invertebrates). Here we review existing ISO standards focusing on their potential use for climate change policies. Table 1 describes the main existing standards that can be used for that purpose; we refer to that table for a specification of all the standards numbers mentioned in this article. The standards listed in this Table are organized in several sections including soil description, soil sampling strategies, and characterization of the collected samples. These standards have been selected for their potential use to measure relevant soil parameters, to describe and to monitor soil status, as well as to parameterize models (e.g., tier 2 regional reference values and Tier 3 mechanistic models). Specific examples of potential applications for the accounting of soil $\mathrm{C}$ stocks and fluxes of GHGs are discussed below.

For Tier 1 level, SOC stocks and GHGs emission factors are already defined in IPCC (2006). Reporting requires only the knowledge on soil types (organic versus mineral), land use and management. ISO 15903 (2002) and ISO 25177 (2008) may provide help to define and share information on soils and site. For Tier 2 and 3, spatial variability (surface and depth) becomes important. The measurement of $\mathrm{C}$ stocks in soil (see Equation 1, adapted from Poeplau et al., 2017), at a given location will at least require the analysis of organic C concentration (ISO 10694, 1995 or ISO 14235,1998 ), bulk density (ISO 11272, 1998), the content of fine and coarse particles (and associated OC and N) (ISO 11277, 2009), and soil depth (ISO 25177, 2008).

$$
C \text { stock }=\sum_{i=1}^{n} 10 \times p_{i} \times S O C_{i} \times B D_{i} \times\left(1-C P_{i}\right)\left({\text { in } \left.\mathrm{kg} . \mathrm{m}^{-2}\right)}^{-2}\right.
$$

Where:

$p_{i}$ (in $\mathrm{m}$ ) is the thickness of the soil layer $i$.

$S O C_{i}$ (in g. $\mathrm{kg}^{-1}$ ) is the organic carbon concentration of layer $i$ in fine soil.

$B D i$ (in kg.dm ${ }^{-3}$ ) is the bulk density of layer $i$ of fine soil.

$C P_{i}$ is the percentage of coarse particles of layer $i$.

$n$ is the number of soil layers.

At larger scales (e.g., landscape, regional, national), highthroughput techniques such as infrared spectroscopic methods may be used to quantify SOC in large soil sample sets (ISO 17184:2014). The sampling strategy should also be defined according to the accuracy needed. As an example, in order to detect $\mathrm{C}$ stock changes within the existing EU soil monitoring networks, Saby et al. (2008) calculated the minimum detectable difference in SOC and showed that only changes at least of

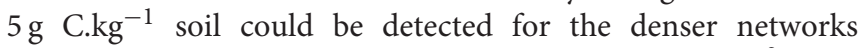
with at least one soil sampling point each $300 \mathrm{~km}^{2}$. ISO 16133 (2004) provides general guidance on the design and maintenance of such soil monitoring programmes but does not specify the requirements needed to detect SOC changes (e.g., time between two consecutive samplings). Considering emissions of GHGs and to forecast SOC changes at Tier 3 level, other parameters should be included, such as soil moisture (ISO 11274, 1998), pH (ISO 10390, 2005), total N

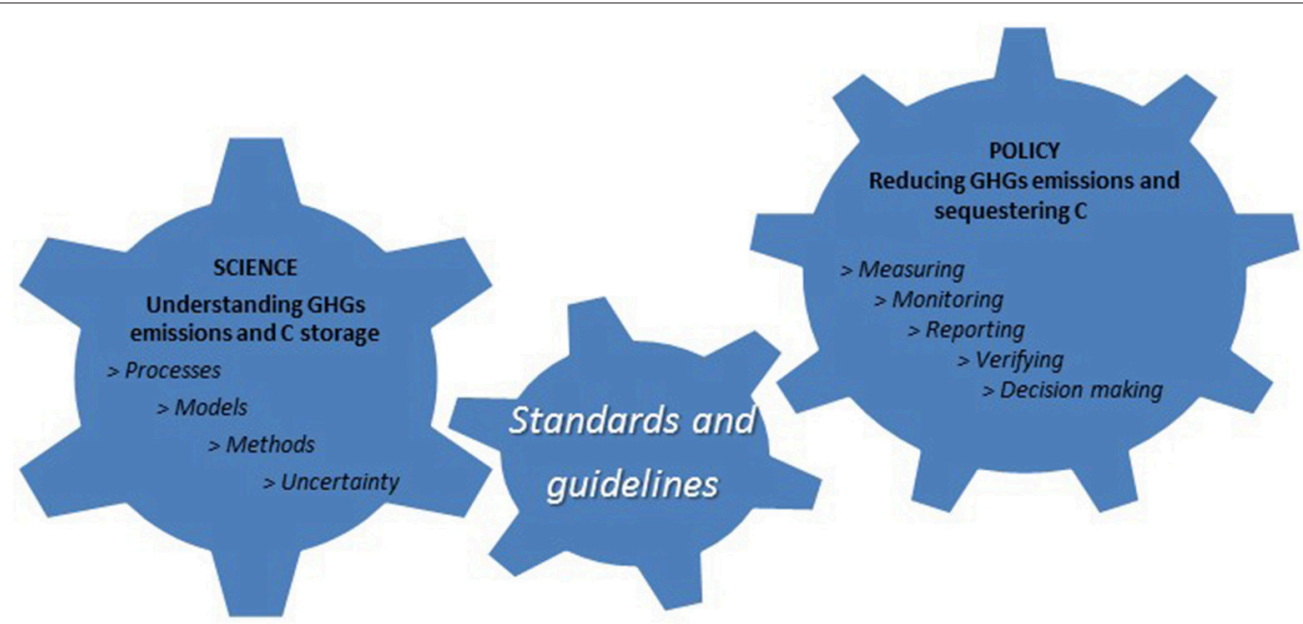

FIGURE 3 | Standards as a link between science and policies. 
TABLE 1 | Main existing ISO standards needed to measure or model GHGs fluxes, C stocks and controlling parameters of soils.

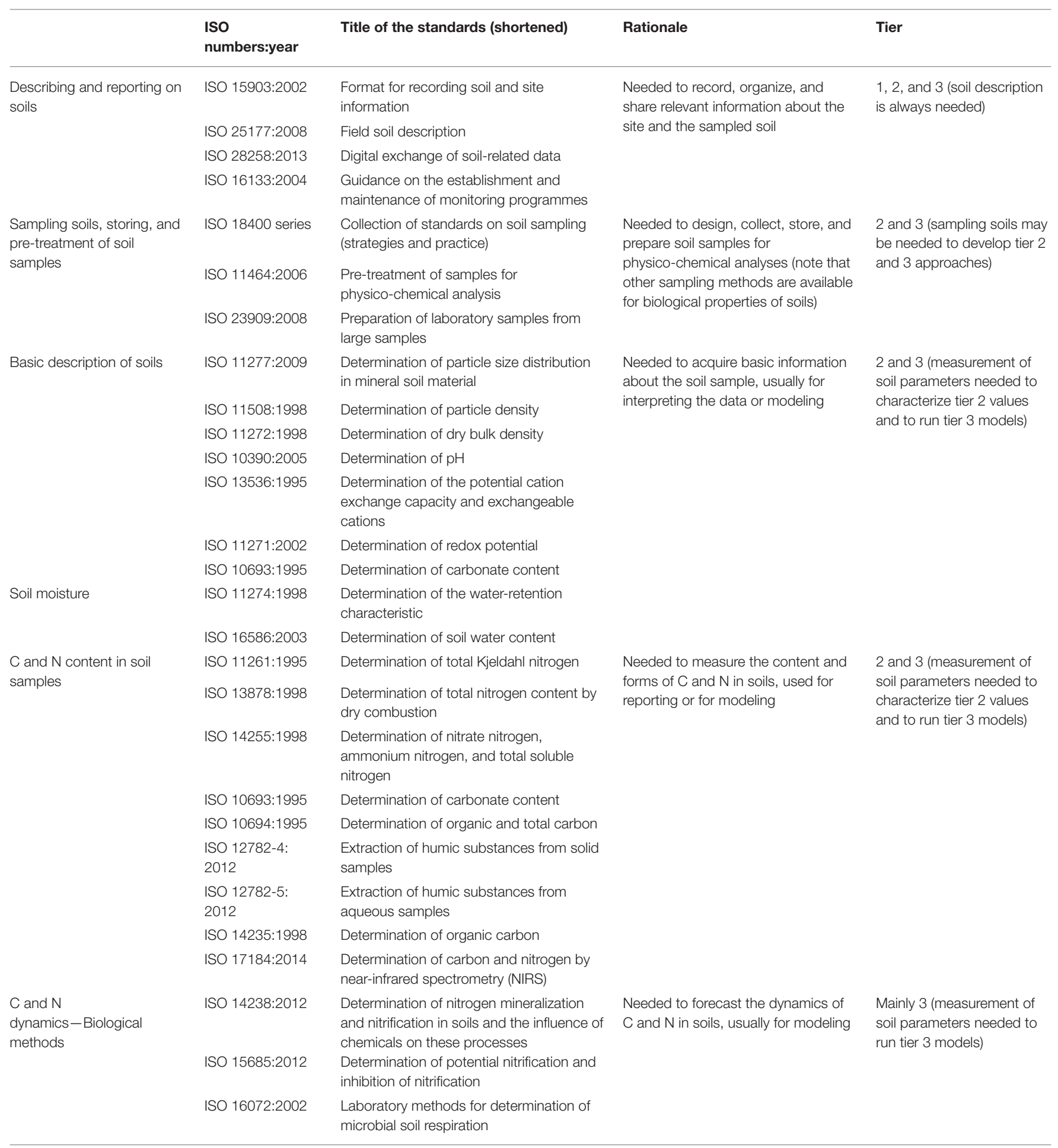

(ISO 11261, 1995 or ISO 13878, 1998), ammonia and nitrate contents (ISO 14255, 1998), texture (ISO 11277, 2009), or biological activities such as the microbial nitrification potential (ISO 15685, 2012). Several models for $\mathrm{N}_{2} \mathrm{O}$ emissions consider physico-chemical parameters (e.g., soil bulk density, moisture,
$\mathrm{pH}$, particle size distribution, $\mathrm{N}$ fractions) together with biological measurements (e.g., the NoE algorithm of Hénault et al., 2005 used in the CERES-EGC model; Gabrielle et al., 2006), which can be obtained from these already available standards. 


\section{NEEDED STANDARDS ACCORDING TO POLICY REQUIREMENTS}

Standards listed in Table $\mathbf{1}$ are already available even though some adjustment may be required to address specific policy needs regarding climate change (e.g., number of samples to be collected depending on scale or time). These existing standards cover mainly the measurement of basic soil parameters together with the status of $\mathrm{C}$ and $\mathrm{N}$ that can be used to monitor their concentration and stocks in soils. No available standard covers the measurement or the forecast of emissions of GHGs from soil and no guideline is yet available to explain how to estimate $\mathrm{C}$ stocks in a landscape or at a regional level. Below we elaborate more specifically on new standards that we suggest to be developed in view of climate policy requirements.

Upcoming climate policies will call for actions regarding the protection and increase of existing SOC stocks (Bernoux and Paustian, 2014; e.g., 4 per mille initiative) and for reducing GHGs emissions. Such measures will require standardized methods (i) to assess the current SOC stocks and emissions at the relevant scales (e.g., farm, region, country, and continent), (ii) to estimate the potential of sequestration and emission mitigation depending on land use (e.g., afforestation) or management changes (e.g., no till), and (iii) to verify the efficiency of the mitigation policies. As already discussed, several standards are available for estimating SOC stocks at the point scale. However, there is still a need for standard guidance documents to estimate stocks at various spatial scales (Stolbovoy et al., 2007; Morvan et al., 2008; Saby et al., 2008; Schrumpf et al., 2011; The Earth Partners LLC, 2012; Chappell et al., 2013; de Gruijter et al., 2016; Miller et al., 2016; Maillard et al., 2017). Rapid, accurate and cost effective procedures (e.g., remote sensing, infrared spectroscopic measurements in the field) are needed to enable frequent monitoring of SOC data on a large scale (Vaudour et al., 2013; Gras et al., 2014; Cambou et al., 2016; Lobsey and Viscarra Rossel, 2016; Ramifehiarivo et al., 2017). Moreover, from a climate change point of view it is also important to provide standard guidance on the detection of SOC stock changes, as these changes can either have a negative (emissions) or beneficial effect on climate change (mitigation). The vertical distribution of SOC stocks within the soil profile should also be carefully monitored in a standardized manner as it can evolve with land use and management (e.g., tillage vs. no-till; Olson and Al-Kaisi, 2015; Poeplau et al., 2017).

Considering GHGs emissions from soils, several protocols have been developed based on chamber methods (de Klein and Harvey, 2012; Epron et al., 2016) or micrometeorological techniques (Laville et al., 1999). Guidelines should provide assistance in choosing the relevant method according to specific needs and scale (Hassouna et al., 2016; ISO WD 20951, 2017). Technical standards should also be proposed to harmonize protocols and improve quality and comparability of data. For example, Rochette and Eriksen-Hamel (2008) analyzed 356 studies using chamber methodology for measuring $\mathrm{N}_{2} \mathrm{O}$ and evaluated that more than half of these studies could not be judged robust because of an inadequate protocol or/and insufficient reporting.

Forecasting $\mathrm{C}$ sequestration in soils and estimating GHGs emissions from soil will require models developed and calibrated at local or at least at regional scales. Standardized soil data, site description (e.g., temperature, rainfall) and land management (e.g., fertilization, tillage) will be needed to model the dynamics of $\mathrm{C}$ and $\mathrm{N}$ in a comparable manner. Several models are available, and standards should provide recommendations for their proper use and validity of the results depending on the scope of the study. Standards should be used for model initialization and/or parameterization, if based on measurable quantities. For example, the YASSO model describes different kinetic pools for litter and SOC, which are determined by chemical extractions in water, ethanol and acid (Tuomi et al., 2011). The size of the soil C pools of the rothC model can also be initialized by a SOC physical fractionation scheme (Zimmermann et al., 2006; Wiesmeier et al., 2016; Nemo et al., 2017). The NoE algorithm (Hénault et al., 2005), which is used to simulate $\mathrm{N}_{2} \mathrm{O}$ emissions in various agroecosystem models, explicitly integrates the soil capacity to reduce $\mathrm{N}_{2} \mathrm{O}$ (Hénault et al., 2001).

Standardized proxies to estimate the capacity of soils to store/lose C and to enhance/reduce GHGs emissions can also help land managers and policy makers to make choices on land use and soil management (Dignac et al., 2017). For example, some authors have proposed that we could calculate a soil C deficit from soil properties including fine particles content (Hassink, 1997; Six et al., 2002; Feng et al., 2013; Beare et al., 2014), and thus estimate the ability of a soil to store additional C. Specific organic matter fractions such as particulate organic matter have been proposed as proxy or early indicators for soil $\mathrm{C}$ changes and thermal analysis can indicate the potential for SOC loss on large soil sample sets (Saenger et al., 2015; da Silva Oliveira et al., 2017; Dignac et al., 2017).

Finally, standards should be developed for the verification of soil C sequestration, for instance in projects where financial compensation is considered. One of the main difficulties in soil $\mathrm{C}$ auditing is to measure $\mathrm{C}$ storage at a manageable cost with appropriate statistical confidence (de Gruijter et al., 2016). Standards are required to provide a common framework and give confidence to investors and policy makers. Table 2 presents standards or guidelines that we suggest to be developed to address the above issues. We propose this work to be developed within ISO TC 190 in close cooperation with other ISO committees (e.g., ISO 207), international initiatives such as the 4 per 1,000 initiative (http://4p1000.org/), the Global Research Alliance (http://globalresearchalliance.org/), the International Soil Carbon Network (http://iscn.fluxdata.org/), and the ICOS Ecosystem Network (http://www.europe-fluxdata.eu/icos/home) to answer policy needs and support IPCC tier 2 and/or 3 approaches.

\section{CONCLUSION}

Soil is a large and essential C stock. It is not only vulnerable to the effects of climate change, it also provides opportunities 
TABLE 2 | Suggested new standards and guidelines to facilitate policy needs.

\begin{tabular}{lll}
\hline Goal & Standards/guides to be developed & Rationale \\
\hline $\begin{array}{ll}\text { Estimate SOC stocks } \\
\text { and GHGs emissions }\end{array}$ & $\begin{array}{l}\text { Guidance documents on soil } \\
\text { sampling for stocks calculation }\end{array}$ & $\begin{array}{l}\text { Recommendations are needed to design } \\
\text { sampling campaigns depending on the scale } \\
\text { (e.g., plot, landscape, nation, continent) and } \\
\text { the observed system (e.g., homogenous } \\
\text { agricultural plot, agroforestry plot) }\end{array}$
\end{tabular}

Guidance documents and/or standards to measure GHGs emissions from soil

Several methods have been developed to measure emissions of GHGs from soil. Recommendations are needed to choose the relevant one according to specific needs and scale

Standards for in situ measurement of $\mathrm{C}$ and $\mathrm{N}$ contents

Standards to measure soil temperature and moisture

imate the poten sequestration and/or rate of GHGs emissions
Standards to measure the different fractions of $\mathrm{C}$ in soils

Standards for measurement and calculation of proxies of soil contribution to GHGs emissions and C storage
Knowledge of soil climate in the field is needed to model emission and the dynamics of organic matter

Soil organic matter consists of a variety of molecular components that may be more or less recalcitrant and/or physically protected against microbial degradation. Knowledge of the size of $\mathrm{C}$ fractions with specific mean residence time in soil can be used to parameterize models of the dynamics of $\mathrm{C}$ in soils

Proxies for the capacity of soils to store/lose C and to enhance/reduce GHGs emissions can help to make choices on land use and soil management
Guidelines to estimate GHGs emissions from soil using models
Recommendations should be made to proper use models and check the validity of the results depending on the scope of the study

\section{Examples of technical and scientific} references

Recommendations for estimating soil C stocks in rocky soils (Poeplau et al., 2017) Plots and soil monitoring networks for detecting soil C stock changes (Stolbovoy et al., 2007; Morvan et al., 2008; Saby et al., 2008; Schrumpf et al., 2011; The Earth Partners LLC, 2012; Chappell et al., 2013)

Protocol for assessing $\mathrm{C}$ stock in alley cropping agroforestery plots (Cardinael et al., 2015)

Chambers method (Rochette and Eriksen-Hamel, 2008; de Klein and Harvey, 2012) or micro-meteorological techniques (Laville et al., 1999) for measuring $\mathrm{CO}_{2}, \mathrm{~N}_{2} \mathrm{O}$ and $\mathrm{CH}_{4}$ emissions (see for example Epron et al., 2016; Hassouna et al., 2016; ISO/DIS 20951, 2017)

A standard for laboratory spectroscopic determination of SOC and total $\mathrm{N}$ concentrations exists (see Table 1), but standards for their spectroscopic determination in the field are needed for both concentrations (Gras et al., 2014) and stocks (Cambou et al., 2016; Lobsey and Viscarra Rossel, 2016)

Remote sensing for mapping topsoil organic C (Vaudour et al., 2013)

Protocols developed by the Integrated Carbon Observation System (ICOS network) could be used (https://www.icos-ri.eu/)

The French standard (NF X31-516, 2007) describes a granulo-densimetric fractionation method of soil organic particulate material known to be more labile in soils. Another soil organic $\mathrm{C}$ physical fractionation scheme has been proposed to initialize the rothC model (Zimmermann et al., 2006; Wiesmeier et al., 2016; Nemo et al., 2017)

Thermal analysis provides reliable and cost-effective information on the biogeochemical stability of soil $\mathrm{C}$ and can be used to estimate the size of soil organic $\mathrm{C}$ fractions (Saenger et al., 2015; Barré et al., 2016; Campo and Merino, 2016)

Soil C saturation capacity (Angers et al., 2011; Wiesmeier et al., 2014) has been proposed to estimate the potential gain of soil organic C. Its relevance for predicting soil $\mathrm{C}$ storage remains to be evaluated (O'Rourke et al., 2015; Dignac et al., 2017)

Physical fractionation of soil organic $\mathrm{C}$ (particulate organic matter fraction) and thermal analysis have been proposed to estimate the potential for soil C loss (Dignac et al., 2017 and references therein)

Soil capacity to reduce $\mathrm{N}_{2} \mathrm{O}$ (Hénault et al., 2001; Jones et al., 2014)

As an example see (Parton et al., 1994; Del Grosso et al., 2008; Kurz et al., 2009; Tuomi et al., 2011; Taghizadeh-Toosi et al., 2014) 
TABLE 2 | Continued

\begin{tabular}{|c|c|c|c|}
\hline Goal & Standards/guides to be developed & Rationale & $\begin{array}{l}\text { Examples of technical and scientific } \\
\text { references }\end{array}$ \\
\hline & $\begin{array}{l}\text { Guidelines to assess the quality of } \\
\text { data and data treatment }\end{array}$ & $\begin{array}{l}\text { Recommendations should be made to check } \\
\text { the quality of data to be used for reporting, } \\
\text { mapping and modeling }\end{array}$ & $\begin{array}{l}\text { As an example for } \mathrm{N}_{2} \mathrm{O} \text { emissions see de Kleir } \\
\text { and Harvey, } 2012\end{array}$ \\
\hline $\begin{array}{l}\text { Verify the effect of } \\
\text { mitigation options }\end{array}$ & $\begin{array}{l}\text { Guidelines to design in space and } \\
\text { time how to sample soils to monitor } \\
\text { the variation of } \mathrm{C} \text { stocks }\end{array}$ & $\begin{array}{l}\text { Recommendations are needed to select the } \\
\text { appropriate way of sampling (time } \times \text { space) } \\
\text { depending on the accuracy needed to detect } \\
\text { changes in C stocks (e.g., early detection or } \\
\text { long term variation) }\end{array}$ & $\begin{array}{l}\text { See Brus and De Gruijter, 1997; de Gruijter } \\
\text { et al., 2006, } 2016\end{array}$ \\
\hline
\end{tabular}

for mitigating emissions of GHGs. It is already observed that significant changes in (i) temperature, (ii) rainfall, (iii) frequency of extreme events (e.g., droughts, frost, heat waves, and fires) will significantly affect soil properties and biological functioning including soil organic matter pools and GHGs emissions. Measuring and reporting both the effect of climate change on soil SOC stocks as well as quantifying the effects of soil-based mitigation measures for GHGs emissions, is crucial to value and finance these measures and develop effective policies. Relevant international standards and guidelines have to be used to evaluate the results in a consistent manner and to ensure both the quality as well as the comparability of data. This paper describes standards already developed within ISO TC 190 for soil quality guidelines and parameters (Table 1) that can be used for this purpose, and calls for the development of new ones (Table 2)

\section{REFERENCES}

Angers, D. A., Arrouays, D., Saby, N. P. A., and Walter, C. (2011). Estimating and mapping the carbon saturation deficit of French agricultural topsoils. Soil Use Manag. 27, 448-452. doi: 10.1111/j.1475-2743.2011.00366.x

Barré, P., Plante, A. F., Cécillon, L., Lutfalla, S., Baudin, F., Bernard, S., et al. (2016). The energetic and chemical signatures of persistent soil organic matter Biogeochemistry 130, 1-12. doi: 10.1111/j.1475-2743.2011.00366.x

Beare, M. H., McNeill, S. J., Curtin, D., Parfitt, R. L., Jones, H. S., Dodd, M. B., et al. (2014). Estimating the organic carbon stabilisation capacity and saturation deficit of soils: a New Zealand case study. Biogeochemistry 120, 71-87. doi: 10.1007/s10533-014-9982-1

Bernoux, M., and Paustian, K. (2014). "Climate change mitigation," in Soil Carbon: Science, Management and Policy for Multiple Benefits, eds S. A. Banwart, E. Noellemeyer, and E. Milne (Wallingford: CABI), 119-131.

Bispo, A., Eglin, T., Feix, I., Le Mouël, C., Gohin, A., Forslund, A., et al. (2014). "On the need of soil data for environmental assessments: the biofuel example," in GlobalSoilMap: Basis of the Global Spatial Soil Information System, eds D. Arrouays, N. McKenzie, J. Hempel, A. Richer de Forges, and B. McBratney Alex (London: CRC Press; Taylor \& Francis Group), 21-25.

Brus, D. J., and De Gruijter, J. J. (1997). Random sampling or geostatistical modelling? Choosing between design-based and modelbased sampling strategies for soil (with discussion). Geoderma 80, 1-44. doi: 10.1016/S0016-7061(97)00072-4

Cambou, A., Cardinael, R., Kouakoua, E., Villeneuve, M., Durand, C., and Barthès, B. (2016). Prediction of soil organic carbon stock using visible and near infrared reflectance spectroscopy (VNIRS) in the field. Geoderma 261, 151-159. doi: 10.1016/j.geoderma.2015.07.007

Campo, J., and Merino, A. (2016). Variations in soil carbon sequestration and their determinants along a precipitation gradient in seasonally dry tropical forest ecosystems. Glob. Change Biol. 22, 1942-1956. doi: 10.1111/gcb. 13244 through international collaboration. Available standards cover the basic soil parameters including $\mathrm{C}$ and $\mathrm{N}$ content but do not yet consider the dynamics of those elements. We propose that such methods be developed together with guidelines taking account of the scale to be investigated and the specific use of the acquired data. By ensuring the quality and comparability of data, such standards can contribute strongly to improve the reliability of climate models and mitigation measures, and thus facilitate effective policy developments.

\section{AUTHOR CONTRIBUTIONS}

All the authors have contributed equally to the discussions leading to this article. $\mathrm{AB}, \mathrm{TE}$, and $\mathrm{MBr}$ have coordinated the redaction of the text.

Cardinael, R., Chevallier, T., Barthes, B., Saby, N., Parent, T., Dupraz, C., et al. (2015). Impact of alley cropping agroforestery on stocks, forms and spatial distribution of soil organic carbon - a case study in a Mediterranean context. Geoderma 259, 288-299. doi: 10.1111/gcb.13244

Chappell, A., Baldock, J. A., and Viscarra Rossel, R. A. (2013). Sampling Soil Organic Carbon to Detect Change Over Time. Department of Environment; CSIRO.

Chenu, C., Klumpp, K., Bispo, A., Angers, D., Colnenne, C., and Metay, A. (2014). Stocker du carbone dans les sols agricoles: évaluation de leviers d'action pour la France. Innov. Agron. 37, 23-37. Available online at: https://www6.inra.fr/ciag/ Revue/Volumes-publies-en-2014/Volume-37-Juillet-2014

Ciais, P., Sabine, C., Bala, G., Bopp, L., Brovkin, V., Canadell, J., et al. (2013). "Carbon and other biogeochemical cycles," in Climate Change 2013: The Physical Science Basis. Contribution of Working Group I to the Fifth Assessment Report of the Intergovernmental Panel on Climate Change, eds T. F. Stocker, D. Qin, G.-K. Plattner, M. Tignor, S. K. Allen, J. Boschung, A. Nauels, Y. Xia, V. Bex, and P. M. Midgley (Cambridge, UK; New York, NY: Cambridge University Press), 465-570.

Citepa (2014). Rapport National d'Inventaire pour la France au titre de la Convention Cadre des Nations Unies sur les Changements Climatiques et du Protocole de Kyoto. Centre interprofessionnel Technique d'Etudes de la Pollution Atmosphérique.

Clough, T., Di, H., Cameron, K., Sherlock, R. R., Metherell, A. K., Clark, H., et al. (2007). Accounting for utilization of a $\mathrm{N}_{2} \mathrm{O}$ mitigation tool in the IPCC inventory methodology for agricultural soils. Nutr. Cycl. Agroecosyst. 78, 1-14. doi: 10.1007/s10705-006-9069-z

Colomb, V., Bockel, L., Chotte, J. L., Martin, S., Tinlot, M., and Bernoux, M. (2013). Selection of appropriate calculators for landscape-scale greenhouse gas assessment for agriculture and forestry. Environ. Res. Lett. 8:015029. doi: 10.1088/1748-9326/8/1/015029

Cox, P. M., Betts, R. A., Jones, C. D., Spall, S. A., and Totterdell, I. J. (2000). Acceleration of global warming due to carbon-cycle feedbacks 
in a coupled climate model. Nature 408, 184-187. doi: 10.1038/350 41539

Crowther, T. W., Todd-Brown, K. E. O., Rowe, C. W., Wieder, W. R., Carey, J. C., Machmuller, M. B., et al. (2016). Quantifying global soil carbon losses in response to warming. Nature 540, 104-108. doi: 10.1038/nature20150

da Silva Oliveira, D. M., Paustian, K., Cotrufo, M. F., Fiallos, A. R., Cerqueira, A. G., and Cerri, C. E. P. (2017). Assessing labile organic carbon in soils undergoing land use change in Brazil: a comparison of approaches. Ecol. Indic. 72, 411-419. doi: 10.1016/j.ecolind.2016.08.041

de Gruijter, J. J., McBratney, A. B., Minasny, B., Wheeler, I., Malone, B. P., and Stockmann, U. (2016). Farm-scale soil carbon auditing. Geoderma 265, 120-130. doi: 10.1016/j.geoderma.2015.11.010

de Gruijter, J., Brus, D. J., Bierkens, M. F. P., and Knotters, M. (2006). Sampling for Natural Resource Monitoring. Berlin; Heidelberg: Springer-Verlag.

de Klein, C., and Harvey, M. (2012). Nitrous Oxide Chamber Methodology Guidelines. Wellington: Global Research Alliance on Agricultural Greenhouse Gases, Ministry for Primary Industries.

Del Grosso, S. J., Parton, W. J., Ojima, D. S., Keough, C. A., Riley, T. H., and Mosier, A. R. (2008). "DAYCENT simulated effets of land use and climate on county level $\mathrm{N}$ loss vectors in the USA," in Nitrogen in the Environment: Sources, Problems, and Management, eds R. F. Follett and J. L. Hatfield (Amsterdam: Elsevier Science Publishers), 571-595. doi: 10.1016/B978-0-12-374347-3.00018-4

Dignac, M. F., Derrien, D., Barré, P., Barot, S., Cécillon, L., Chenu, C., et al. (2017). Increasing soil carbon storage: mechanisms, effects of agricultural practices and proxies. a review. Agron. Sustain. Dev. 37:14. doi: 10.1007/s13593-017-0421-2

Eglin, T., Ciais, P., Piao, S. L., Barre, P., Bellassen, V., Cadule, P., et al. (2010). Historical and future perspectives of global soil carbon response to climate and land-use changes. Tellus 62, 700-718. doi: 10.1111/j.1600-0889.2010.00499.x

Environment Canada (2015). National Inventory Report, 1990-2013: Greenhouse Gas Sources and 1504 Sinks in Canada. Available online at: ec.gc.ca/ges-ghg/ default.asp?lang=En\&n=83A34A7A- 1

Epron, D., Plain, C., Ndiaye, F. K., Bonnaud, P., Pasquier, C., and Ranger, J. (2016). Effects of compaction by heavy machine traffic on soil fluxes of methane and carbon dioxide in a temperate broadleaved forest. For. Ecol. Manage. 382, 1-9. doi: 10.1016/j.foreco.2016.09.037

EU (2013). Decision no 529/2013/EU of the European Parliament and of the Council of 21 May 2013 on Accounting Rules on Greenhouse Gas Emissions and Removals Resulting from Activities Relating to Land Use, Land-Use Change and Forestry and on Information Concerning Actions Relating to Those Activities. EU.

European Commission (2012). COM(2012) 595 Proposal for a Directive of the European Parliament and of the Council Amending Directive 98/70/EC Relating to the Quality of Petrol and Diesel Fuels and Amending Directive 2009/28/EC on the Promotion of the Use of Energy from Renewable Sources. European Commission.

European Commission (2015). Directive 1513 of the European Parliament and of the Council Amending Directive 98/70/EC Relating to the Quality of Petrol and Diesel Fuels and Amending Directive 2009/28/EC on the Promotion of the Use of Energy from Renewable Sources. European Commission.

Fargione, J., Hill, J., Tilman, D., Polasky, S., and Hawthorne, P. (2008). Land clearing and the biofuel carbon debt. Science 319, 1235-1237. doi: $10.1126 /$ science. 1152747

Feng, W., Plante, A. F., and Six, J. (2013). Improving estimates of maximal organic carbon stabilization by fine soil particles. Biogeochemistry 112, 81-93. doi: 10.1007/s10533-011-9679-7

Fujisaki, K., Perrin, A.-S., Desjardins, T., Bernoux, M., Balbino, L. C., and Brossard, M. (2015). From forest to cropland and pasture systems: a critical review of soil organic carbon stocks changes in Amazonia. Glob. Change Biol. 21, 2773-2786. doi: $10.1111 /$ gcb.12906

Gabrielle, B., Laville, P., Hénault, C., Nicoullaud, B., and Germon, J. C. (2006). Simulation of nitrous oxide emissions from wheat-cropped soils using CERES. Nutr. Cycl. Agroecosyst. 74, 133-146. doi: 10.1007/s10705-005-5771-5

Gras, J.-P., Barthès, B. G., Mahaut, B., and Trupin, S. (2014). Best practices for obtaining and processing field visible and near infrared (VNIR) spectra of topsoils. Geoderma 214, 126-134. doi: 10.1016/j.geoderma.2013.09.021

Harris, Z. M., Spake, R., and Taylor, G. (2015). Land use change to bioenergy: a meta-analysis of soil carbon and GHG emissions. Biomass Bioenergy 82, 27-39. doi: 10.1016/j.biombioe.2015.05.008
Hassink, J. (1997). The capacity of soils to preserve organic C and N by their association with clay and silt particles. Plant Soil 191, 77-87. doi: 10.1023/A:1004213929699

Hassouna, M., Eglin, T., Cellier, P., Colomb, V., Cohan, J. P., Decuq, C., et al. (2016). Measuring Emissions from Livestock Farming: Greenhouse Gases, Ammonia and Nitrogen Oxides. INRA-ADEME Edition. Available online at: https://www6.inra.fr/animal_emissions_eng/News/Book-2015-Measuringemissions-from-livestock-farming

Hénault, C., Bizouard, F., Laville, P., Gabrielle, B., Nicoullaud, B., Germon, J. C., et al. (2005). Predicting in situ soil $\mathrm{N}_{2} \mathrm{O}$ emission using NOE algorithm and soil database. Glob. Chang. Biol. 11, 115-127. doi: 10.1111/j.1365-2486.2004.00879.x

Hénault, C., Chèneby, D., Heurlier, K., Garrido, F., Perez, S., and Germon, J. C. (2001). Laboratory kinetics of soil denitrification are useful to discriminate soils with potentially high levels of $\mathrm{N}_{2} \mathrm{O}$ emission on the field scale. Agronomie 21, 713-723. doi: 10.1051/agro:2001165

IPCC (2003). Good Practice Guidance for Land Use Change, Land Use Change and Forestry. Hayama: Institute for Environmental Strategies. Intergovernmental Panel on Climate Change. Available online at: http://www.ipcc-nggip.iges.or. jp/public/gpglulucf/gpglulucf.html

IPCC (2006). Guidelines for National Greenhouse Gas Inventories Agriculture Forestry and Other Land Use (AFOLU), Vol. 4. Hayama: Institute for Environmental Strategies. Intergovernmental Panel on Climate Change. Available online at: http://www.ipcc-nggip.iges.or.jp/public/2006gl/index.html

ISO 14064-1 (2006). Greenhouse Gases-Part 1: Specification with Guidance at the Organization Level for Quantification and Reporting of Greenhouse Gas Emissions and Removals. ISO.

ISO 14064-2 (2006). Greenhouse Gases-Part 2: Specification with Guidance at the Project Level for Quantification, Monitoring and Reporting of Greenhouse Gas Emission Reductions or Removal Enhancements. ISO.

ISO 14064-3 (2006). Greenhouse Gases-Part 3: Specification with Guidance for the Validation and Verification of Greenhouse Gas Assertions. ISO.

ISO/DIS 20951 (2017). Guidelines for Measuring Greenhouse Gases Emissions from Agricultural and Forest Soils. ISO/DIS.

ISO/TR 14069 (2013). Greenhouse Gases-Quantification and Reporting of Greenhouse Gas Emissions for Organizations-Guidance for the Application of ISO 14064-1. ISO/TR.

ISO/TS 14067 (2013). Greenhouse Gases-Carbon Footprint of Products Requirements and Guidelines for Quantification and Communication. SO/TS.

Janzen, H. H. (2004). Carbon cycling in earth systems-a soil science perspective. Agric. Ecosyst. Environ. 104, 399-417. doi: 10.1016/j.agee.2004.01.040

Jobbàgy, E. G., and Jackson, R. B. (2000). The vertical distribution of soil organic carbon and its relation to climate and vegetation. Ecol. Appl. 10, 423-436. doi: 10.1890/1051-0761(2000)010[0423:TVDOSO]2.0.CO;2

Jones, C. M., Spor, A., Brennan, F. P., Breuil, M. C., Bru, D., Lemanceau, P., et al. (2014). Recently identified microbial guild mediates soil $\mathrm{N}_{2} \mathrm{O}$ sink capacity. Nat. Clim. Change 4, 801-805. doi: 10.1038/nclimate2301

Kuikman, P. J., van der Hoek, K. W., Smit, A., and Zwart, K. A. (2006). Update of Emissions Factors for Direct Emissions of Nitrous Oxide from Agricultural Soils on the Basis of Measurements in the Netherlands. Alterra Report 1217, Alterra, Wageningen.

Kurz, W. A., Dymond, C. C., White, T. M., Stinson, G., Shaw, C. H., Rampley, G. J., et al. (2009). CBM-CFS3: a model of carbon-dynamics in forestry and land-use change implementing IPCC standards. Ecol. Modell. 220, 480-504. doi: 10.1016/j.ecolmodel.2008.10.018

Lal, R. (2016). Beyond COP 21: potential and challenges of the " 4 per thousand" initiative. J. Soil Water Conserv. 71, 20A-25A. doi: 10.2489/jswc.71.1.20A

Lal, R., Follett, R. F., Stewart, B. A., and Kimble, J. M. (2007). Carbon sequestration to mitigate climate change and advance food security. Soil Sci. 172, 943-956. doi: 10.1097/ss.0b013e31815cc498

Laville, P., Jambert, C., Cellier, P., and Delmas, R. (1999). Nitrous oxide fluxes from a fertilised maize crop using micrometeorological and chamber methods. Agric. Forest Meteorol. 96, 19-38. doi: 10.1016/S0168-1923(99)00054-4

Le Gall, C., Cellier, P., and Hénault, C. (2015). “Emissions par les sols du gaz à effet de serre $\mathrm{N}_{2} \mathrm{O}$-De l'étude des processus biologiques aux inventaires nationaux d'émissions," in Empreinte Carbone: Evaluer et Agir, eds B. Bourges, T. Gourdon, and J. S. Broc (Paris: Presses des Mines, collection Développement Durable), 27-50. 
Lobsey, C. R., and Viscarra Rossel, A. (2016). Sensing of soil bulk density for more accurate carbon accounting. Eur. J. Soil Sci. 67, 504-513. doi: 10.1111/ejss.12355

Maillard, É., McConkey, B. G., and Angers, D. A. (2017). Increased uncertainty in soil carbon stock measurement with spatial scale and sampling profile depth in world grasslands: a systematic analysis. Agric. Ecosyst. Environ. 236, 268-276. doi: 10.1016/j.agee.2016.11.024

McNally, S. R., Beare, M. H., Curtin, D., Meenken, E. D., Kelliher, F. M., Calvelo Pereira, R., et al. (2017). Soil carbon sequestration potential of permanent pasture and continuous cropping soils in New Zealand. Glob. Change Biol. doi: 10.1111/gcb.13720. [Epub ahead of print].

Miller, B. A., Koszinski, S., Hierold, W., Rogasik, H., Schröder, B., Van Oost, K., et al. (2016). Towards mapping soil carbon landscapes: issues of sampling scale and transferability. Soil Till. Res. 156, 194-208. doi: 10.1016/j.still.2015.07.004

Milne, E., Neufeldt, H., Rosenstock, T., Smalligan, M., Cerri, C. E., Malin, D., et al. (2013). Methods for the quantification of GHGs emissions at the landscape level for developing countries in smallholder contexts. Environ. Res. Lett. 8:015019. doi: 10.1088/1748-9326/8/1/015019

Minasny, B., Malone, B. P., McBratney, A. B., Angers, D. A., Arrouays, D., Chambers, A., et al. (2017). Soil carbon 4 per mille. Geoderma 292, 59-86. doi: 10.1016/j.geoderma.2017.01.002

Montanarella, L. (2015). Govern our soils. Nature 528:32. doi: 10.1038/528032a

Montanarella, L., and Alva, I. L. (2015). Putting soils on the agenda: the three Rio conventions and the post-2015 development agenda. Curr. Opin. Environ. Sustain. 15, 41-48. doi: 10.1016/j.cosust.2015.07.008

Montanarella, L., and Vargas, R. (2012). Global governance of soil resources as a necessary condition for sustainable development. Curr. Opin. Environ. Sustain. 4, 559-564. doi: 10.1016/j.cosust.2012.06.007

Morvan, X., Saby, N. P. A., Arrouays, D., Le Bas, C., Jones, R. J. A., Verheijen, F. G. A., et al. (2008). Soil monitoring in Europe: a review of existing systems and requirements for harmonisation. Sci. Total Environ. 391, 1-12. doi: 10.1016/j.scitotenv.2007.10.046

Mosier, A. R., Duxbury, J. M., Freney, J. R., Heinemeyer, O., Minami, K., and Johnson, D. E. (1998). Mitigating agricultural emissions of methane. Clim. Change. 40, 39-80. doi: 10.1023/A:1005338731269

Nemo, K. K., Coleman, K., Dondini, M., Goulding, K., Hastings, A, Jones, M. B., et al. (2017). Soil organic carbon (SOC) equilibrium and model initialisation methods: an application to the Rothamsted carbon (RothC) model. Environ. Model. Assess. 22, 215-229. doi: 10.1007/s10666-016-9536-0

NF X31-516 (2007). Fractionnement Granulo-Densimétrique des Matières Organiques Particulaires du sol Dans l'eau. AFNOR.

Oenema, O., Wrage, N., Velthof, G. L., van Groenigen, J. W., Dolfing, J., and Kuikman, P. J. (2005). Trends in global nitrous oxide emissions from animal production systems. Nutr. Cycling Agroecosyst. 72, 51-65. doi: 10.1007/s10705-004-7354-2

O'Rourke, S. M., Angers, D. A., Holden, N. M., and McBratney, A. B. (2015). Soil organic carbon across scales. Glob. Chang. Biol. 21, 3561-3574. doi: $10.1111 / \mathrm{gcb} .12959$

Olson, K. R., and Al-Kaisi, M. M. (2015). The importance of soil sampling depth for accurate account of soil organic carbon sequestration, storage, retention and loss. Catena 125, 33-37. doi: 10.1016/j.catena.2014.10.004

Parton, W. J., Ojima, D. S., Cole, C. V., and Schimel, D. S. (1994). "A general model for soil organic matter dynamics: sensitivity to litter chemistry, texture and management," in Quantitative Modelling of Soil Forming Processes, eds R. B Bryant and R. W. Arnold (Madison, WI: Soil Science Society of America), $147-167$.

Paustian, K., Lehmann, J., Ogle, S., Reay, D., Robertson, G. P., and Smith, P. (2016). Climate-smart soils. Nature 532, 49-57. doi: 10.1038/nature17174

Plevin, R. J., O'Hare, M., Jones, A. D., Torn, M. S., and Gibbs, H. K. (2010). Greenhouse gas emissions from biofuels' indirect land use change are uncertain but may be much greater than previously estimated. Environ. Sci. Technol. 44, 8015-8021. doi: 10.1021/es101946t

Poeplau, C., Vos, C., and Axel, D. (2017). Soil organic carbon stocks are systematically overestimated by misuse of the parameters bulk density and rock fragment content. Soil 3:61. doi: 10.5194/soil-3-61-2017

Ramifehiarivo, N., Brossard, M., Grinand, C., Andriamananjara, A., Razafimbelo, T., Rasolohery, A., et al. (2017). Mapping soil organiccarbon on a national scale: towards an improved and updated map of Madagascar. Geoderma 9, 29-38. doi: 10.1016/j.geodrs.2016.12.002
Rochette, P., and Eriksen-Hamel, N. S. (2008). Chamber measurements of soil nitrous oxide flux: are absolute values reliable? Soil Sci. Soc. Am. J. 72, 331-342. doi: 10.2136/sssaj2007.0215

Rochette, P., Worth, D. E., Lemke, R. L., McConkey, B. G., Pennock, D. J., WagnerRiddle, C., et al. (2008). Estimation of $\mathrm{N}_{2} \mathrm{O}$ emissions from agricultural soils in Canada. Soil Sci. Soc. Am. J. 68, 493-506. doi: 10.2136/sssaj2004.4930

Saby, N., Bellamy, P. H., Morvan, X., Arrouays, D., Jones, R. J., Verheijen, F. G., et al. (2008). Will European soil-monitoring networks be able to detect changes in topsoil organic carbon content? Glob. Chang. Biol. 14, 2432-2442. doi: 10.1111/j.1365-2486.2008.01658.x

Saenger, A., Cécillon, L., Poulenard, P., Bureau, F., De Danieli, S., Gonzalez, J. M., et al. (2015). Surveying the carbon pools of mountain soils: a comparison of physical fractionation and Rock-Eval pyrolysis. Geoderma 241-242, 279-288. doi: 10.1016/j.geoderma.2014.12.001

Schrumpf, M., Schulze, E. D., Kaiser, K., and Schumacher, J. (2011). How accurately can soil organic carbon stocks and stock changes be quantified by soil inventories? Biogeosciences 8, 1193-1212. doi: 10.5194/bg-8-1193-2011

Schulte, R. P. O., O'Sullivan, L., Coyle, C., Farrelly, N., Gutzler, C., Lanigan, G., et al. (2016). Exploring climate-smart land management for atlantic Europe. Agric. Environ. Lett. 1:160029. doi: 10.2134/ael2016.07.0029

Searchinger, T., Heimlich, R., Houghton, R. A., Dong, F., Elobeid, A., Fabiosa, J., et al. (2008). Use of U.S. croplands for biofuels increases greenhouse gases through emissions from land-use change. Science 319, 1238-1240. doi: $10.1126 /$ science. 1151861

Six, J., Conant, R. T., Paul, E. A., and Paustian, K. (2002). Stabilization mechanisms of soil organic matter: implications for C-saturation of soils. Plant Soil 241, 155-176. doi: 10.1023/A:1016125726789

Smith, P. (2004). Carbon sequestration in croplands: the potential in Europe and the global context. Eur. J. Agron. 20, 229-236. doi: 10.1016/j.eja.2003.08.002

Smith, K. A., and Conen, F. (2004). Impacts of land management on fluxes of trace greenhouse gases. Soil Use Manage. 20, 255-263. doi: 10.1111/j.1475-2743.2004.tb00366.x

Stockmann, U., Adams, M. A., Crawford, J. W., Field, D. J., Henakaarchchi, N., Jenkins, M., et al. (2013). The knowns, known unknowns and unknowns of sequestration of soil organic carbon. Agric. Ecosyst. Environ. 164, 80-99. doi: 10.1016/j.agee.2012.10.001

Stolbovoy, V., Montanarella, L., Filippi, N., Jones, A., Gallego, J., and Giacomo, G. (2007). Soil Sampling Protocol to Certify Changes of Organic Carbon Stock in Mineral Soil of the European Union-Version 2. Scientific and Technical Research Series. Luxembourg: EUR.

Taghizadeh-Toosi, A., Olesen, J. E., Kristensen, K., Elsgaard, L., Ostergaard, H. S., Laegdsmand, M., et al. (2014). Changes in carbon stocks of Danish agricultural mineral soils between 1986 and 2009. Eur. J. Soil Sci. 65, 730-740. doi: $10.1111 /$ ejss. 12169

Thamo, T., and Pannell, D. J. (2015). Challenges in developing effective policy for soil carbon sequestration: perspectives on additionality, leakage, and permanence. Clim. Policy 16, 1-20. doi: 10.1080/14693062.2015.10 75372

The Earth Partners LLC. (2012). VCS Module vmd0021. Estimation of Stocks in the Soil Carbon Pool. The Earth Partners LLC.

Tuomi, M., Rasinmäki, J., Repo, A., Vanhala, P., and Liski, J. (2011). Soil carbon model Yasso07 graphical user interface. Environ. Model. Softw. 26, 1358-1362. doi: 10.1016/j.envsoft.2011.05.009

UNCCD (2015). Science - Policy Brief 01. Edited by United Nations convention to combat desertification. UNCCD.

UNFCCC (2011). Decision 2/CMP.7 of the Conference of the Parties serving as the Meeting of the Parties to the Kyoto Protocol, Adopted by the 17th Conference of the Parties of the UNFCCC meeting in Durban in December 2011. UNFCCC.

UNFCCC (2016a). FCCC/CP/2015/10/Add.1.Report of the Conference of the Parties on its Twenty-First Session, Held in Paris from 30 November to 13 December 2015. Addendum. Part Two: Action Taken by the Conference of the Parties at its Twenty-First Session. UNFCCC.

UNFCCC (2016b). FCCC/SBSTA/2015/INF.7. Report on the Workshop on the Assessment of Risk and Vulnerability of Agricultural Systems to Different Climate Change Scenarios at Regional, National and Local Levels, Including but not Limited to Pests and Diseases. UNFCCC.

Vaudour, E., Bel, L., Gilliot, J. M., Coquet, Y., Hadjar, D., Cambier, P., et al. (2013). Potential of SPOT multispectral satellite images for mapping topsoil organic 
carbon content over peri-urban croplands. Soil Sci. Soc. Am. J. 77, 2122-2139. doi: 10.2136/sssaj2013.02.0062

Webb, N., Broomfield, M., Buys, G., Cardenas, L., Murrels, T., Pang, Y., et al. (2014). UK Greenhouse Gas Inventory, 1990 to 2012. Available online at: http:// naei.defra.gov.uk/reports/reports?report_id=789

Wiesmeier, M., Hübner, R., Spörlein, P., Geuss, U., Hangern, E., Reischl, A., et al. (2014). Carbon sequestration potential of soils in southeast Germany derived from stable soil organic carbon saturation. Glob. Chang. Biol. 20, 653-665. doi: $10.1111 /$ gcb.12384

Wiesmeier, M., Poeplau, C., Sierra, C. A., Maier, H., Frühauf, C., Hübner, R., et al. (2016). Projected loss of soil organic carbon in temperate agricultural soils in the 21st century: effects of climate change and carbon input trends. Sci. Rep. 6:32525. doi: 10.1038/srep32525

Zhang, J., Müller, C., and Cai, Z. (2015). Heterotrophic nitrification of organic N and its contribution to nitrous oxide emissions in soils. Soil Biol. Biochem. 84, 199-120. doi: 10.1016/j.soilbio.2015.02.028

Zilberman, D. (2017). Indirect land use change: much ado about (almost) nothing. GCB Bioenerg. 9, 485-488. doi: 10.1111/gcbb.12368
Zimmermann, M., Leifeld, J., and Schmidt, M. W. I. (2006). Measured soil organic matter fractions can be related to pools in the RothC model. Eur. J. Soil Sci. 58, 658-667. doi: 10.1111/j.1365-2389.2006. 00855.x

Conflict of Interest Statement: The authors declare that the research was conducted in the absence of any commercial or financial relationships that could be construed as a potential conflict of interest.

Copyright (c) 2017 Bispo, Andersen, Angers, Bernoux, Brossard, Cécillon, Comans, Harmsen, Jonassen, Lamé, Lhuillery, Maly, Martin, Mcelnea, Sakai, Watabe and Eglin. This is an open-access article distributed under the terms of the Creative Commons Attribution License (CC BY). The use, distribution or reproduction in other forums is permitted, provided the original author(s) or licensor are credited and that the original publication in this journal is cited, in accordance with accepted academic practice. No use, distribution or reproduction is permitted which does not comply with these terms. 